\title{
Nietzsche, Polytheism and Parody
}

\section{Pierre Klossowski}

Parody and polytheism in Nietzsche? At first sight, it is not at all clear what relation exists between these two terms, nor what kind of concerns would lead one to speak of them, nor what interest one might have in raising such a question. If for most people Nietzsche's name is inseparable from the utterance God is dead, then it may seem surprising to speak of the religion of many gods with regard to Nietzsche. After all, there are countless people today for whom Nietzsche's name signifies nothing more than this utterance-and they did not need Nietzsche to know that all the gods are dead. It may also seem, perhaps, that I am simply using Nietzsche to demonstrate the existence of many gods and to legitimate polytheism; and, by playing on these words, I will not escape the reproach, under the pretext of showing the meaning of parody in Nietzsche, of making a parody of myself and thus of parodying Nietzsche.

If I must open myself to such confusion, I would nevertheless like to make one thing clear: insofar as one is lead to interpret the thought of a mind [esprit] that one tries to comprehend and make comprehensible, there is no one who leads his interpreter to parody him as much as Nietzsche. 
This is true not only of those interpreters who are smitten with his thought, but also those who try hard to refute him as a dangerous spirit. Nietzsche himself urged one of his first interpreters-no one had yet spoken of him-to abandon all pathos, not to take sides in his favor, and to put up a sort of ironic resistance when characterizing him.

Here, then, we cannot avoid being the victim of a sort of ruse, nor can we avoid falling into the trap inherent in Nietzsche's own experience and thought. Unless we simply undertake the work of the historian, as Andler did, ${ }^{1}$ the moment we try to elucidate Nietzsche's thought, he is always made to say more than he says and less than he says. This is not-as is often the case with other thinkers-due to a simple lack of perspective or even because a determinate point of departure has been omitted. In assimilating Nietzsche, we make him say more than he says, while in rejecting or altering him, we make him say less than he says-for the simple reason that, properly speaking, with Nietzsche there is hardly either a point of departure or a precise terminus. Nietzsche's contemporaries and friends were able to follow an evolution from The Birth of Tragedy to The Wanderer and His Shadow and on to The Gay Science, and from Zaratbustra to The Twilight of the Idols. But those of us who have at our disposal the youthful writings as well as the posthumous work, including Ecce Homo, have not only been able to follow the ramifications of Nietzsche's posterity, and to witness the accusations made against Nietzsche as a result of recent historical upheavals, but have also been able to discern something which, I think, is not without importance: Nietzsche, who was despite everything a professor of philology at Basel, and thus an academic with absolutely certain pedagogical ambitions, did not develop a philosophy. Instead, outside of the framework of the university, Nietzsche developed variations on a personal theme. Living a simple life marked by extreme suffering and convalescence, forced to sojourn with increasing frequency at health resorts, while in the midst of the greatest intellectual isolation, Nietzsche was thereby abandoned, in the most 


\section{PIERRE KLOSSOWSKI}

auspicious manner, to listen to himself alone [à sa seule audition].

This academic, trained in the disciplines of science in order to teach and train others, found himself compelled to teach the unteachable. What is unteachable are those moments when existence, escaping from the delimitations that produce the notions of history and morality, as well as the practical behavior derived from them, is shown to be given back to itself with no other goal than that of returning to itself. All things then appear at once new and quite old; everything is possible and everything is immediately impossible; and there are only two courses open to consciousness: either to keep silent, or to speak; either to do nothing, or to act so as to imprint on one's everyday quotidian ambiance the character of existence given back to itself; either to lose itself in existence or to reproduce it.

Nietzsche had immediately attained this unteachable in his own solitude, through his own idiosyncrasies- - that is, by describing bimself as a convalescent who had suffered from the unresolved nihilism of his own era and who had resolved this nihilism, to the point where he was able to restore to the notion of fatum its full force. He had grasped the very ground of existence, lived as fortuitous - that is, he had grasped that aspect of existence which, through him, was fortuitously named Nietzsche. In this way, he had also grasped the necessity of accepting this fortuitous situation as his own destiny (in the sense he ascribes to this word), which amounts to a decision to affirm the existence of a universe that has no other end than that of being what it is.

Nietzsche recognized this apprehension of existence-which is nothing other than the apprehension of eternity-in the simulacra of art and religion, but he also saw that this mode of apprehension is perpetually denied by scientific activity, which explores existence through its tangible forms in order to construct a practicable and livable world. Nonetheless, Nietzsche felt a solidarity with both these attitudes toward existence: that of simulacra, as well as that of science, which declares fiat veritas pereat vita. ${ }^{2}$ 
And so be put simulacra into science and science into simulacra: in such a way that the scientist can say: "Qualis artifex pereop"3

Nietzsche was prey to an inelucidable revelation of existence that did not know how to express itself except through song and image. A struggle was being waged within him between the poet and the scholar, between the visionary and the moralist, each of which was trying to disqualify the role of the other. This struggle was provoked by a feeling of moral responsibility toward his contemporaries. The different tendencies, the different attitudes that were fighting over Nietzsche's consciousness would endure until a crucial event was produced: Nietzsche would be externalized in a character, a veritable dramatis persona: Zarathustra-a chatacter who is not only the product of a fictive redoubling, but is in some way a challenge by Nietzsche the visionary to Nietzsche the professor and man of letters. The character of Zarathustra has a complex function: on the one hand, he is the Christ, as Nietzsche secretly and jealously understands him; but on the other hand, insofar as he is the Accuser of the traditional Christ, he is the one who prepares the way for the advent of Dionysus philosophos.

The years during which Thus Spoke Zaratbustra was fashioned, and especially those that followed its birth, were for Nietzsche a state of unparalleled distress:

One pays dearly for immortality: one has to die several times while still alive. There is something that I call the rancor of what is great: everything great-a work, a deed-is no sooner accomplished than it turns against the man who did it. By doing it, he has become weak; he no longer endures his deed, he can no longer face it. Something one was never permitted to will lies bebind one, something in which the knot in the destiny of humanity is tied-and now one labors under it!-It almost crushes one... ${ }^{4}$ 


\section{PIERRE KLOSSOWSKI}

Zarathustra, to be sure, was latent in the previous works, but what is important for Nietzsche's life is not only the creation and presence of the ineffable songs of the poem. What came to be determinant for Nietzsche's life was the more or less complete identification of Nietzsche with this physiognomy, which for him constituted a kind of promise, a resurrection, an ascension. In a certain sense, Zarathustra is the star of which Nietzsche himself is only the satellite. Even better, I would say that Nietzsche, after having paved the way for the triumph of Zarathustra, remains behind in a position sacrificed in the course of a victorious retreat. As he himself said, he would pay dearly for this creation. Zarathustra prefigures Nietzsche's own immortality-that immortality by which one dies more than once while still alive. When Nietzsche managed to separate Zarathustra from himself, and was thereby able to encounter him as a superior but still inaccessible reality, then the world of appearances-which, according to the divine fable, was created in six days-disappeared along with the true world; for in six days the true world became a fable once again. Nietzsche casts a retrospective glance at this re-fabulation of the true world that disappears in six days, or six periods, which are the inverse of the six days of the world's creation. It is this re-fabulation that he traces out in an aphorism of The Twilight of the Idols entitled "How the True World' Finally Berame a Fable."

Here is the passage:

1. The true world-attainable for the sage, the pious, the virtuous man; he lives in it, he is it. (The oldest form of the idea...a circumlocution for the sentence, "I, Plato, am the truth.")

2. The true world - unattainable for now, but promised for the sage, the pious, the virtuous man, "for the sinner who repents." (Progress of the idea: it becomes more subtle, insidious, incomprehensible... it becomes 
Christian.)

3. The true world-unattainable, indemonstrable, unpromisable; but the very thought of it-a consolation, an obligation, as an imperative. (At bottom, the old sun, but seen through mist and skepticism. The idea has become elusive, pale, Nordic, Königsbergian.)

4. The true world-unattainable? At any rate, unattained. And being unattained, also unknown. Consequently, not consoling, redeeming, or obligating: how could something unknown obligate us? (Gray morning. The first yawn of reason. The cockcrow of positivism.)

5. The true world-an idea which is no longer good for anything, not even obligating-an idea that has become useless and superfluous-consequently, a refuted idea: let us abolish it! (Bright day...return of bon sens and gaiety: Plato's embarrassed blush; pandemonium of all free spirits.)

6. The true world--we have abolished. What world has remained? The apparent one perhaps? But no! With the true world we have abolished the apparent one. (Noon; moment of the shortest shadow; end of the longest error:

Incipit Zaratbustra!) ${ }^{5}$

With the true world, we have abolished the apparent world. When the true world (the Platonic, Christian, spiritualist, idealist, transcendental world) that serves as the point of reference for the apparent world disappears, then the apparent world disappears as well. The apparent world cannot become the real world of scientific positivism: the world becomes a fable, the world as such is only a fable. "Fable" means something that is narrated, and that exists only in its narration. 
The world is something that is narrated, a narrated event, and hence an interpretation. Religion, art, science, and history are so many diverse interpretations of the world, or rather, so many variants of the fable.

Is this to say that we are dealing here with a universal illusionism? Not at all. The fable, I said, is an event that is narrated; it happens, or rather, it must make something happen; and in effect an action takes place and narrates itself; but if we are not content to listen and follow, if we seek to apprehend the narration in order to discern whether bebind the recitation there is not some moment that differs from what we understand in the narration, then everything is interruptedand once again, there is a true world and an apparent world. We have seen how the true world and the apparent world have become a fable, but this is not the first time. There is something in Nietzsche's text that warrants mention: midday, hour of the shortest shadow. After midday, everything begins again, including the ancient world, that is to say, the past interpretations. In antiquity, the hour of midday was an hour at once lucky and ill-fated [faste et néfaste], not only an hour in which all activity was suspended under the blinding light of the sun, but also an hour of forbidden visions, followed by delirium. After midday, the day declines into shadows; but through these shadows, we will be guided to profound midnight by Zarathustra, the master of the fable.

Fable, fabula, comes from the Latin verb fari, which means both "to predict" and "to rave" [prédire et divaguer], to predict fate and to rave; fatum, fate, is also the past participle of fari.

Thus when we say that the world has become fable, we are also saying that it is a fatum; one raves, but in raving one foretells and predicts fate. We emphasize these connotations here because of the role that fatality--the crucial notion of fatum-plays in Nietzsche's thought. 'The re-fabulation of the world also means that the world exits historical time in order to reenter the time of myth, that is, eternity. Or rather, it means that the vision of the world is an apprehension of 
eternity. Nietzsche saw that the mental conditions for such an "exit" [sortie] lay in the forgetting (of the historical situation) that was preliminary to the act of creating: in forgetting, the past is remembered [sous-vient à] by humans as their future, which takes the figure of the past. ${ }^{6}$ It is in this way that the past comes to [advient] them in what they create; for what they believe they create in this way does not come to them from the present, but is only the pronunciation of a prior possibility in the momentary forgetting of the (historically determined) present.

Zarathustra's mission is to give a new meaning and a new will to men in a world that he is necessarily going to recreate. But since every created world risks losing its meaning and becoming fabulous and divine once again, and since it may be rejected and seem intolerable to men now that they have come to will nothing rather than something, Zarathustra must reveal to them the true way, which is not a straight path but a tortuous one:

For bere is all my creating and striving, that I create and carry together into one what is fragment and riddle and dreadful chance.

Along with the true world, we have abolished the apparent world-along with the preoccupation with truth, we have liquidated the explanation of appearances. (" Explanation' is what we call it, but it is 'description' that distinguishes us from older stages of knowledge and science. Our descriptions are better-but we do not explain any more than our predecessors." 8 ) All this is full of consequence, for if the thought of having abolished the apparent world along with the true world is not a simple quip, it gives an account of what was happening in Nietzsche himself. He had given notice to the world in which he still carried the name of "Nietzsche" (and if he continued to write under this name, it was in order to save appearances): everything has changed and nothing has changed. It is better to let those who act believe they are changing something. Does not Nietzsche say that these people are not, in fact, men of action, but rather contemplatives who put a price on 
things-and that men of action act only by virtue of this appreciation by the contemplatives?

But this suppression of the apparent world, with its reference to the true world, finds expression in a long process that can be followed only if we take into account the coexistence, within Nietzsche, of the scientist and the moralist-or more essentially, the psychologist and the visionary. Two different terminologies result from this, which, in their perpetual interference, form an inescapable web. In the end, the lucidity of the psychologist, the destroyer of images, will simply be put to work by the poet, and thus for the fable. In his attempt to scrutinize the lived experience of the poet - the sleepwalker of the day-the psychologist would discover regions in which he himself was dreaming out loud.

This analysis of the psychologist, before he was invaded by the dreams and visions he tried to avoid, allows us to see succinctly how, in the name of the rational principles of positivism, Nietzsche winds up ruining not only the rational concept of truth but also the concept of conscious thought, including the operations of the intellect; and how, on the other hand, this depreciation of conscious thought leads Nietzsche to question the validity of any communicability through language; and we can see more clearly how this analysiswhich reduces rational thought to impulsive forces, but which attributes to these impulsive forces the quality of authentic existence-leads to a suppression of the limits between the outside and the inside, a suppression of the limits between existence individuated bere and now and existence returning to itself within the person of the philosopher. What presides over this disintegration of concepts-for obviously something must subsist-is always the intensity of the mind which has been excited to a supreme degree of insomnia; a sustained perspicacity that drives to despair the demand for integrity, a perspicacity whose rigor goes so far as to want to be liberated from these functions of thought as if from a final servitude, a final link with what Nietzsche called "the spirit of gravity." The analysis of consciousness that Nietzsche gives in 
various aphorisms of The Gay Science may be summarized in the following observations:

1. Consciousness was the latest function to develop in the evolution of organic life; it is also the most fragile function, and consequently, the most dangerous one. If humanity had become conscious all at once, as it has been believed, it would have perished a long time ago. The proof of this lies in the great number of false steps that consciousness has provoked in the life of the species, and that it continues to provoke in the live of individuals, insofar as it creates a disequilibrium in their impulses.

2. This undesirable function (undesirable because it corresponds to an incompatible aspiration, the aspiration to truth) undergoes an initial adaptation to other impulsive forces; for a time, consciousness is linked to the life-conserving instinct; and then one forms the fallacious notion of a consciousness that is stable, eternal, immutable and, consequently, free and responsible. Because of this overestimation of consciousness, its over-hasty elaboration has been avoided. From this arises the notion of substance.

3. The mental operations that this (opportunely retarded) consciousness develops in its elaboration-these operations that constitute logical reason and rational knowledge-are merely the products of this compromise between the impulsive life and consciousness. From what is logic born? Obviously from the illogicality whose domain was originally immense. At this stage, according to Nietzsche's positivist description, logic becomes the strongest weapon of the impulses, particularly for those beings in which aggressiveness is translated into affirmation or negation, while illogicality remains the domain of the weakest impulses. Opportunely retarded in its own development, consciousness (as false consciousness) develops conscious thought out of the need to communicate through language. Such is the origin of the most subtle operations that constitute logical reason and rational knowledge.

At bottom, every high degree of caution in 


\section{PIERRE KLOSSOWSKI}

making inferences and every skeptical tendency constitute a great danger for life. No living beings would have survived if the opposite tendency-to affirm rather than suspend judgment, to err and make up things rather than wait, to assent rather than negate, to pass judgment rather than be just-had not been bred to the point where it became extraordinarily strong. ${ }^{9}$

4. Consciousness, as a threatening function because of its anti-vital aspiration, therefore finds itself momentarily in retreat. In the relationship of knowledge, however, this dangerous power is manifested anew in its true light. Logical reason, constructed by the impulses in the course of this combat with the anti-vital tendency of consciousness, engenders habits of thinking which the still-maladapted tendency of consciousness is led to detect as errors. These errors - which are precisely those that make life possible, and which Nietzsche will later recognize as forms for the apprehension of existence-always observe the same rules of the game: namely, that there are durable things; that objects, materials, and bodies exist; that a thing is what it appears to be; that our will is free; that what is good for me is good in an intrinsic manner--ingrained propositions that have become the norms in accordance with which logical reason establishes the true and the non-true. "It was only very late," says Nietzsche, "that truth emerged-as the weakest form of knowledge. It seemed that one was unable to live with it: our organism was prepared for the opposite." ${ }^{\prime 10}$ Hence, Nietzsche remarks, the strength of different sorts of knowledge does not reside in their degree of truth, but in their degree of antiquity, their degree of incorporation, their character as conditions for life. Nietzsche here cites the example of the Eleatics, who wanted to put our sensible perceptions in doubt. The Eleatics, he says, believed it was possible to live the antinomies of the natural errors. But in order both to affirm the antinomy and to live it, they invented the sage, a person who 
was both impersonal and unchangeable, and thus they fell into illusion (I am still citing Nietzsche). Unable to abstract from their own human condition, misunderstanding the nature of the knowing subject, and denying the violence of the impulses in knowledge, the Eleatics, in an absolute fashion, believed they could conceive of reason as a perfectly free activity. Probity and skepticism, those dangerous manifestations of consciousness, were able to develop in ever more subtle ways at the moment when these two contradictory propositions appeared to be applicable to life because both were compatible with fundamental errors-the moment it became possible to dispute about their greater or lesser degree of utility for life. Likewise, other new propositions, while not useful to life, were nonetheless not harmful to life because they were simply expressions in an intellectual game; and consequently, they bore witness to the innocent and fortunate character of every game. At that moment, the act of knowing and the aspiration to the true were finally integrated as one need among other needs. Not only belief or conviction, but also examination, negation, mistrust, or contradiction constituted a power [une puissance], such that even the bad instincts were subordinated and placed in the service of knowledge, and acquired the prestige of what is licit, venerated, and useful-and ultimately the look and innocence of the Good. Nietzsche thereby comes to this first conclusion on the precise situation of the philosopher:

The thinker is now that being in whom the impulse to truth and those life-preserving errors clash for their first fight, after the impulse for truth has proved to be also a life-preserving power. ${ }^{11}$

The impulse to truth is a life-conserving power? But here this is only a hypothesis, a momentary concession. In fact, Nietzsche concludes with a question: "To what extent can truth endure incorporation? That is the question; that is the experiment to be performed [l'experience à faire]."12

Nietzsche himself will carry this experiment to its conclusion. When Nietzsche evoked the example of the 


\section{PIERRE KLOSSOWSKI}

Eleatics as an attempt to live the natural antinomies-an attempt that required the impossible impersonality of the philosopher in order to succeed-it was his own experience that he was projecting into the past. The Eleatics, said Nietzsche, invented the figure of the impersonal and immutable sage as being both One and All. In so doing, they fell into illusion, Nietzsche declares, because they remained unaware of the violence of the impulses in the knowing subject. But if Nietzsche, in this judgment against the Eleatics, presents himself as the person in whom this illusory experience has been brought to consciousness, it is precisely because he himself, obscurely, aspires to be both One and All, as if he now saw the secret of the experiment in a return of consciousness to the unconscious, and of the unconscious to consciousness-so completely and so well that, at the end as at the beginning, it would seem that the true world exists nowhere else than in the sage.

Here, we must immediately distinguish between the experiment to be performed and the lived experience [l'expérience à faire et l'expérience vécue], between the suffering and the willing.

In effect, we would like to know if the lived experience-Nietzsche's specific experience, the ecstasy of the eternal return in which the ego would suddenly find itself to be both One and All, One and Multiple-could be made the object of a demonstration, and thus constitute the point of departure for a moral teaching.

But we must confine ourselves here to the question we posed earlier: Could the philosopher have knowledge of a state in which he would be both One and All, one and multiple, given the fact that he will always ascribe more and more consciousness to his pathos?

In other words: How could he possess his pathos knowingly insofar as the pathos would be an apprehension of existence returning upon itself?

In aphorism 333 of The Gay Science, Nietzsche provides a commentary on one of Spinoza's propositions that takes us 
to the heart of this problem:

The meaning of knowing.- Non ridere, non lugere, neque detestari, sed intelligere! says Spinoza as simply and sublimely as is his wont. Yet in the last analysis, what else is this intelligere than the form in which we come to feel the other three at once? One result of the different and mutually opposed impulses to laugh, lament, and curse? Before knowledge is possible, each of these impulses must first have presented its one-sided view of the thing or the event; after this comes the fight between these onesided views, and occasionally this results in a mean, one grows calm, one finds all three sides right, and there is a kind of justice and a contract; for by virtue of justice and a contract all these instincts can maintain their existence and assert their rights against each other. Since only the last scenes of reconciliation and the final accounting at the end of this long process rise to our consciousness, we suppose that intelligere must be something conciliatory, just, and good-something that stands essentially opposed to the instincts, while it is actually nothing but a certain behavior of the instincts toward one anotber.

For the longest time, conscious thought was considered thought itself. Only now does the truth dawn on us that by far the greatest part of our spirit's activity remains unconscious and unfelt. But I suppose that these instincts which are here contending against one another understand very well how to make themselves felt by, and how to hurt, one another. This may well be the source of that sudden and violent exhaustion that afflicts all thinkers (it is the exhaustion on a battlefield). 
Indeed, there may be occasions of concealed beroism in our warring depths, but certainly nothing divine that eternally rests in itself, as Spinoza supposed. Conscious thinking, especially that of the philosopher, is the least vigorous and therefore also the relatively mildest and calmest form of thinking; and thus precisely philosophers are most apt to be led astray about the nature of knowledge.

In this very beautiful passage, I suspect that Nietzsche has defined, in a negative manner, his own mode of comprehending and knowing: ridere, lugere, detestari (laughing, crying, hating) are three ways of apprehending existence. But what is a science that laughs, or cries, or detests? A pathetic knowledge? Our pathos knows, but we are never able to share its mode of knowing. For Nietzsche, every intellectual act corresponds to variations of a state of humor. Now, to attribute a character of absolute value to pathos ruins, in a single blow, the notion that knowledge is impartial, since it was only from an acquired degree of impartiality that one called into doubt that same impartiality. This ingratitude is the inverse of knowledge, which is disavowed as soon as it makes us comprehend that we cannot know-an ingratitude that will give birth to a new impartiality, but within an absolute partiality. For if logical conclusions are nothing but the conflict among the impulses that can only end in something unjust, to aspire to more partiality would be to observe the highest justice.

If the thinker, as Nietzsche says, is the being in whom the impulse to truth and the life-preserving errors live and struggle together, and if the question is knowing to what extent truth can bear incorporation-if that is the experiment that must now be performed-then let us now try to see in what sense pathos is capable of this incorporation as an apprehension of existence. Now that the intellectual act has been devalorized-since it only takes place at the price of a supreme exhaustion-why not admit bilarity as much as seriousness as an organ of knowledge, for example, or anger 
as much as serenity? Once seriousness is admitted to be a state as doubtful as hatred or even love, why could not hilarity be as valid and obvious an apprehension of existence as seriousness?

The act of knowing, judging, or concluding is nothing but the result of a certain behavior of the impulses toward each other. Moreover, conscious thought-especially the thought of the philosopher-is most often the expression of a fall, a depression provoked by a terrible quarrel between two or three contradictory impulses that results in something unjust in itself. Does this mean that the philosopher (or the thinker or the sage, in the Nietzschean sense) should give himself over to a similarly contradictory behavior among the impulses? Or that he should never speak except in statements that participate in two or three simultaneous impulses, thereby giving an account of existence apprehended through these two or three impulses?

If the act of comprehending something is at this point suspect-since it never reaches a conclusion except by eliminating one of the impulses that has, in varying degrees, contributed to its formation-and if comprehending is nothing other than a precarious armistice between obscure forces, then, out of this concern for integrity that directs Nietzsche's investigation so as to bring more consciousness to our impulsive forces, comprehending can act only by exercising a perpetual complicity with our tendencies, good or bad. However, does it not seem that this illusion is worse than the one for which Nietzsche reproached Spinoza, when Spinoza opposed the act of comprehending to the fact of laughing, crying, and hating? How can an obscure force reach consciousness as an obscure force if it does not already belong to the full light of consciousness? As the Apostle said, "All things that are condemned are made manifest by the light, for whatever makes manifest is light." 13 How to manifest without condemning? How can an obscure force be made manifest without condemning itself to be illuminated? Could there not be a light that is not a condemnation of the shadows? Pathos knows, no doubt, 
but we cannot share in its mode of knowing except through this condemnation: "Take no part in the unfruitful works of the shadows," said the Apostle. ${ }^{14}$ Nevertheless, it is written that "the light shines in the darkness, but the darkness did not receive it. "'5 The light wanted to be received by the shadows; there is thus a moment when the light is a condemnation, and there is a moment when the light seeks to be received by the shadows.

Everything that rises up into the full light of consciousness rises up upside down-the images of night are reversed in the mirror of conscious thought. Later we will see that there is a necessity deeply inscribed in the law of being that is explicated as the universal wheel, the image of eternity-and that the results of this law is the inversion of night into day, and of sleep into the wakefulness of consciousness. Conscious thought is constituted only in and through an ignorance of this law of return. Every conscious thought looks forward, identifying itself with a goal that it posits before itself as its own definition. But if conscious thought tends to invert the images of the night in full day, this is because, in taking exteriority as a point of departure, it claims to be speaking, even as it mistranslates an original text of which it is unaware. As Nietzsche says:

Consciousness does not really belong to man's individual existence.... The thinking that rises to consciousness is only a tiny part of ourselvesthe most superficial and worst part-for only this conscious thinking takes the form of words, which is to say, signs of communication....The emergence of our sense impressions into our own consciousness, the ability to fix them and, as it were, exhibit them externally, increased proportionally with the need to communicate them to others by means of signs....Consciousness has developed subtlety only insofar as this is required by social or herd utility. Consequently, given the best will in the world to understand ourselves as individually 
as possible, 'to know ourselves,' each of us will only succeed in becoming conscious only of what is not individual but 'average'....Fundamentally, all our actions are altogether incomparably personal, unique, and infinitely individual; there is no doubt of that. But as soon as we translate them into consciousness they no longer seem to be. ${ }^{16}$

To conclude: every coming to consciousness is the result of an operation of generalization, of falsification, and thus is a fundamentally ruinous operation.

It is not the opposition of subject and object that concerns me here: this distinction I leave to the epistemologists who have become entangled in the snares of grammar (the metaphysics of the people). It is even less the opposition of 'thing-in-itself' and appearance; for we do now 'know' nearly enough to be entitled to any such distinction. We simply lack any organ for knowledge, for 'truth': we 'know' (or believe or imagine) just as much as may be useful in the interests of the human herd, the species; and even what is here called 'utility' is ultimately also a mere belief, something imaginary, and perhaps precisely that most calamitous stupidity of which we shall perish someday. ${ }^{17}$

According to this definition, what conscious thought produces is always only the most utilizable part of ourselves, because only that part is communicable; what we have of the most essential part of ourselves will thus remain an incommunicable and non-utilizable pathos.

By the individual, by the personal, by the most essential part of ourselves, Nietzsche in no way means what is generally understood by the term "individualism." We will see, on the contrary, that the individual and the non-individual will be linked in an indiscernible unity, which is indicated by this very 
concern for the authentic. But here we encounter a number of difficulties in Nietzsche.

If conscious thought inevitably betrays what we have of the most essential part of ourselves, how can this essential aspect be communicated to us? How can it be distinguished from the gregarious and, since the gregarious is always tainted by the pejorative notion of utility, how will this essential aspect of ourselves escape our own utilitarian thought? Will what is authentic in us be something entirely useless in its integrity, and thus properly valuable in Nietzsche's sense, such that here we at last find an apprehension of existence that is sufficient in itself, a possibility of being both One and All?

For conscious thought-the so-called gregarious thought that reveals nothing essential of ourselves, the thought disqualified by Nietzsche-the greatest distress is to remain without a goal, for example, the absence of a truth to be sought for and attained as the supreme goal of conscious thought. By its nature and by definition, conscious thought in itself is always projecting itself forward in search of a goal.

On the other hand, the greatest pleasure of our pathos-the unconscious life of the impulses, the essential aspect of ourselves-is to be without any goal. Inversely, if the belief in a goal makes consciousness happier and procures a degree of security for conscious thought, the effect of this assignation of an end is felt (or can be felt) in our pathos only as the greatest distress. When Nietzsche critiques Spinoza, he means nothing other than this. For although the impulses as needs are obviously unaware of what consciousness wants, they nevertheless imagine that of which they are themselves the need. As soon as consciousness posits a goal, the impulses momentarily lose this image they have of themselves. As images of themselves, the impulses are alienated from their own image for the benefit of the goal-of which they are, by nature, unaware.

If the essential aspect of ourselves lies in our pathoswhich is inexpressible or incommunicable by itself-then insofar as it forms the ensemble of our impulsive life, it also 
constitutes an ensemble of needs. But does it not then seek to satisfy itself in its own dissipation [dépense] ${ }^{18}$ And how would this dissipation effect itself and find satisfaction? When our deepest need expresses the most essential part of ourselves in laughter and tears, for example, it would dissipate itself as laughing and crying, which are in themselves the image of this need. The laughing and crying would be produced independently of any motive that conscious thought would attribute to them, rightly or wrongly, from its goal-oriented perspective. And being thus dissipated, our most profound need and the loss of any goal would coincide, for an instant, with our profound happiness.

Even when we do not know how to share its mode of understanding, our pathos does not thereby prevent us from understanding ourselves. For where do such sudden satisfactions, coupled with the absence of any rational motive, come from-for instance, when I laugh or cry, seemingly without reason, before some spectacle such as those offered by the view of a suddenly-discovered landscape or of tidal pools at the edge of the ocean? Something is laughing or crying in us that, by making use of us, is robbing us of ourselves and concealing us from ourselves; but which, by making use of us, is concealing itself. Does this mean that this something was not present otherwise than in the tears and laughter? For if I laugh and cry in this way, I take myself to be expressing nothing but the immediate vanishing of this unknown motive, which has found in me neither figure nor sense, apart from the image of this forest or these waves greedy for buried treasures. In relation to this unknown motive, which is hidden from me by these outward images, I am, in Nietzsche's sense, only a fragment, an enigma to myself, a borrifying chance. And I will remain a fragment, an enigma, and a chance in relation to that most essential aspect of myself, which speaks through this laughter and these tears without any rational motive. But this most essential aspect of myself, which is made manifest in this way, corresponds to an image hidden in the full light of consciousness, an image that appears to me as inverted and 
that arrives late in the goal-oriented perspective, which wants to lend as much consciousness as possible to this laughter or to these tears. Thus there must be a necessity that wills me to laugh or cry as if I were crying or laughing freely. But is not this necessity the very same necessity that inverts night into day, which inverts sleep into the wakefulness where consciousness posits its goal? Is this not the same necessity that will reinvert the images of the day into those of night? To live and to think in the goal-oriented perspective is to distance myself from what is most essential in me, or from the necessity that testifies, within me, to my deepest need. To want to recuperate this most essential part of myself amounts to living backwards from my consciousness, and therefore I will put all my will and confidence in the necessity that bas made me laugh and cry without any motive. For the movement that throws consciousness out of the night and into the dawn, where it posits its goal, is the same movement that carries me far from this goal in order to lead me back, at deepest midnight, to what I have that is most essential. To suffer this necessity is one thing; it is quite another thing to adhere to it as a law; and still another thing to formulate this law in the image of a circle.

We have seen that the aspiration to truth is given to us as an impulse, and that this impulse becomes identified with the function of consciousness. Consequently, to ask whether the aspiration to truth can be assimilated to pathos and its errors amounts to asking whether pathos can produce something that it must still assimilate. Thus, if consciousness simply pursues this aspiration as its own impulse, by this very fact that impulse works toward its own ruin in the name of truth. What is this thing that pursues such an impulsive aspiration, this thing or this state of things that consciousness posits, in the full light of day, under the name of truth and as its own end? What is this word "truth" if not the inverted image of what produced this impulse to truth as a need? To re-invert this ultimate impulse called the "aspiration to truth"-this aspiration of the totality of pathos taken together-to re-invert the image of this aspiration would come 
down to formulating what Nietzsche states in the following proposition: "Truth is an error without which a certain species of life could not live. The value for life is ultimately decisive." 19 The most recent aspiration that has come to life-this dangerous aspiration to truth-is nothing other than the return of pathos in its totality in the form of a goal.

But here we discover something disquieting in Nietzsche. What did he mean by posing the question of knowing if truth could endure its incorporation as a condition of life? What did he mean by saying that the impulsive aspiration to truth had become life-preserving at the same time as the natural errors? Are not these questions asked from the viewpoint of conscious and gregarious thought, that is, in the terms of the very consciousness that necessarily gives itself a goal? And would not the terms "error" and "truth," which had previously been emptied of their gregarious meaning, immediately be filled again with this same content?

For the philosopher (or the thinker or the sage in the Nietzschean sense), the question is: "What form could be given to this experience so that it could be taught?" How could the will be persuaded to will the opposite of every goal given by conscious thought, such that the will could strive to recuperate its most essential and least communicable aspect? How could the will be persuaded to take itself as its own object, thereby producing an apprehension of existence returning to itself just as the will returns to itself? Was it not necessary to appeal to conscious thought, and thus to borrow from the language of the herd (in this case, the language of positivism), and thus to take up once again the notions of utility and goal, and direct them toward and against every utility, toward and against every goal?

In his retrospective preface to The Gay Science, dated 1886, we read:

'Incipit tragedia' is written at the end of this book, with a disquieting casualness-Beware! Something downright wicked and malicious is announced here: incipit parodia. ${ }^{20}$ 
In the first aphorism of The Gay Science, Nietzsche asks:

What is the meaning of the ever new appearance of these founders of moralities and religions...these teachers of remorse and religious wars? What is the meaning of these heroes on this stage?....It is obvious that these tragedians, too, promote the interest of God or work as God's emissaries. They, too, promote the life of the species by promoting the faith in life. 'Life is worth living,' every one of them shouts; 'there is something to life, there is something behind life, beneath it; beware! From time to time this instinct, which is at work equally in the highest and basest menthe instinct for the preservation of the species-erupts as reason and as passion of the spirit. Then it is surrounded by a resplendent retinue of reason and tries with all the force at its command to make us forget that at bottom it is instinct, drive, folly, lack of reasons. Life shall be loved, because-! Man shall advance himself and his neighbor, because-1....In order that what happens necessarily and always, spontaneously and without any purpose, may henceforth appear to be done for some purpose and strike man as rational and an ultimate commandment, the ethical teacher comes on the stage, as the teacher of the purpose of existence; and to this end he invents a second, different existence and unhinges by means of his new mechanics the old, ordinary existence." 21

And Nietzsche concludes:

Not only laughter and gay wisdom but the tragic, too, with all its sublime unreason, belongs among the means and necessities of 
the preservation of the species. Consequently-. Consequently. Consequently. $\mathrm{O}$, do you understand me, my brothers? Do you understand this new law of ebb and flood? There is a time for us, too! ${ }^{22}$

Does this mean that Nietzsche in turn would like to enter the stage as a new doctor of the goal of existence? As a new doctor of morality? Does this mean that, in order to come to the aid of the most essential aspect of ourselves, we must inevitably appeal to the rationalizations of conscious thought and the positing of a goal-even though it is a question of apprehending an existence without a goal? Nietzsche always has a formula that seems to imply an imperative: the will to power.

This entails a serious question: what is Nietzsche's true language? Is it the language of lived experience, or of inspiration, or of revelation, or perhaps of the experiment to be performed, the language of experimentation? Is there not, in each case, an interference between these various languages, which intervenes in the desire to legitimate the incommunicable lived experience of the eternal return by way of a demonstration? Does not Nietzsche provide this demonstration at the level of the scientifically verifiable cosmos-and on the moral plane, by elaborating an imperative that can command the will under its relation to the will to power? Is this not the point where the dubious references to science and biology intervene, when Nietzsche's fundamental experience is already being expressed on an entirely different level by the character of Zarathustra? Perhaps we have here one of the alternating terms, one of the aspects of Nietzsche's antinomy: the experience of the eternity of the self at the ecstatic moment of the eternal return of all things could not be the object of an experimentation any more than it could be the object of a rationally constructed elucidation; any more than the lived, inexpressible, and therefore incommunicable experience could ground an ethical imperative that would turn the lived into something willed and rewilled, insofar as the 
universal movement of the eternal return is supposed to lead the will to will infallibly at the willed moment. The lived experience is thus entirely implicit in a contemplation where the will is completely absorbed in an existence rendered to itself-so that the will to power is simply an attribute of existence, which wills itself only insofar as it is. This explains the often doubtful character of those propositions of Nietzsche's, in the fragments on the transvaluation of values, that consider will to power independently of the law of the eternal return, independently of this revelation from which it is inseparable. At the level of lived experience, Nietzsche is already surpassed by his own Zarathustra. Nietzsche is no more than the doctor of a counter-morality that is seemingly expressed in clear language, and whose worth comes from this audacious use of conscious thought for the benefit of that which has no goal. $\mathrm{He}$ is the doctor of a goal for existence, charged with covering up his own retreat into that region where, in reality, he has already retired - this immortality from which he has perished, as he says more than once, and from which he will return in delirious transports to show what he is under two different names: Dionysus and the Crucified.

After the proposition: Truth is a necessary error, we find this other proposition: Art is a bigher value than truth, which is the conclusion of those propositions which declare that art prevents us from losing ourselves in the trutb or art protects us from the truth. All these propositions have the same pragmatic character as the preceding proposition: truth is only a necessary error ${ }^{23}$-a character that holds precisely because everything is being considered solely from the viewpoint of its usefulness.

Nevertheless, as soon as error creates forms, it goes without saying that art must effectively become that domain where willed error inaugurates a rule of the game. Just as it is contradictory to give a practical application of truth as error, so it appears that, in this domain of the game par excellence which is art, imposture constitutes a legitimate activity in accord with the reason of fiction. But art has a very wide meaning, and in Nietzsche, this category includes institutions as much 
as works of free creation. For example-and here we can see immediately what is at issue-how does Nietzsche consider the Church? For him, the Church is constituted grosso modo by a cast of profound impostors: the priests. The Church is a masterpiece of spiritual domination, and it required that impossible plebian monk, Luther, to dream of ruining that masterpiece, the last edifice of Roman civilization among us. The admiration Nietzsche always had for the Church and the papacy rests precisely upon the idea that truth is an error, and that art, as willed error, is higher than truth. This is why Zarathustra confesses his affinity with the priest, and why, in the Fourth Part, during that extraordinary gathering of the different kinds of higher men in Zarathustra's cave, the Popethe Last Pope-is one of the prophet's guests of honor. ${ }^{24}$ This betrays, I think, Nietzsche's temptation to foresee a ruling class of great meta-psychologists who would take charge of the destinies of future humanity, since they would know perfectly both the different aspirations and the different resources capable of satisfying them. What interests us, however, is a particular problem that never ceased to preoccupy Nietzsche: the problem of the actor. We read in aphorism 361 of The Gay Science:

Falseness with a good conscience; the delight in simulation exploding as a power that pushes aside one's so-called 'character,' flooding it and at times extinguishing it; the inner craving for a role and mask, for appearance; an excess of the capacity for all kinds of adaptations that can no longer be satisfied in the service of the most immediate and narrow utility-all of this is perhaps not only peculiar to the actor. $^{25}$

Let us take careful note of everything Nietzsche is revealing here: delight in simulation exploding as a power; pushing aside one's so-called "character," submerging it sometimes to the point of extinguishing it-here we suddenly perceive what was threatening Nietzsche himself: first of all, simulation exploding 


\section{PIERRE KLOSSOWSKI}

as power to the point of submerging or extinguishing one's so-called "character." 'The point here is that simulation is not only a means but also a power - and thus that there is an irruption of something incompatible with one's so-called "character," a putting into question of what one is in a situation that has been determined by this same indeterminable. Nietzsche calls this putting into question a surplus of the adaptive faculties, but this surplus, he remarks, never manages to satisfy itself, or to serve an immediate and strict utility. This is why that which is expressed by thus surplus of the faculties of adaptation has a role, which is existence itself-existence without a goal, existence sufficient unto itself. But let us return, once again, to the first line: falseness with a good conscience. Here we confront anew the notion of the willed error. In the rationality of simulacra, it is willed error that provides an account of that existence whose very essence lies in the truth that conceals itself, that refuses itself.

Existence seeks a pbysiognomy in order to reveal itself; the actor is its medium. What reveals existence? A possible physiognomy: perhaps that of a god.

In another curious passage from The Gay Science (aphorism 356), entitled "How things will become ever more 'artistic' in Europe," Nietzsche remarks that the need to make a living compels almost all Europeans to adopt a particular role, their "occupation." Some people manage to retain the merely apparent freedom of choosing this role for themselves, while for most people it is prescribed in advance. The result is quite singular: almost everyone identifies themselves with their role-everyone forgets at what point chance, disposition, and arbitrariness were at work in them when the question of their so-called "vocation" was decided-and how many other roles they might perhaps have been able to play, although now it is too late. In a more profound sense, the role has actually become character, and art bas become nature. Later, the same aphorism discusses the question of social degradation, but what I would like to emphasize is this: what is here described as a phenomenon of contemporary social life appears in reality as the image of destiny itself-and of Nietzsche's destiny in particular. We 
believe we choose freely to be what we are, but not being what we are, we are in fact constrained to play a role-and thus to play the role of what we are outside ourselves. We are never where we are, but always where we are only the actor of this other that we are. The role represents the fortuitousness in the necessity of destiny. We cannot not will, but we can never will something other than a role. To know this is to play in good conscience, and to play as well as possible amounts to dissimulating oneself. Thus, to be a professor of philology at Basel or even the author of Zarathustra is nothing other than to play a role. What one dissimulates is the fact that one is nothing other than existence, and one dissimulates the fact that the role one plays refers to existence itself.

This problem of the actor in Nietzsche, and this irruption of a power in a so-called "character" that threatens to submerge it to the point of extinguishing it--this problem, I am saying, is immediately relevant to Nietzsche's own identity, to the putting in question of this identity considered as fortuitously received and then taken on as a role--just as the role someone chooses to play can be rejected as a mask in favor of another one from among the thousands of masks of history. Having produced this conception from the valorization of the willed error, the valorization of imposture as a simulacrum, it now remains to determine to what extent the simulacrum, if it is an apprehension of existence, constitutes a manifestation of being in the existent being--a manifestation of being in the fortuitous existent.

Is existence still capable of a God? asks Heidegger. This question is asked as much in the biographical context of the person who formulates it for the first time as a piece of newsGod is dead-as it is asked in the context of the events and the thought of the contemporary epoch.

The day after his collapse, in Turin, Nietzsche awakens with the feeling of being both Dionysus and the Crucified, and he signs the letters he sends to Strindberg, Burckhardt, and other notable figures with one of these divine names.

Until this point, it had always been a matter of 


\section{PIERRE KLOSSOWSKI}

opposing Dionysus and the Crucified: "Have I been understood? Dionysus versus the Crucified." 26 Now that Nietzsche the professor has faded-or rather, now that he has finally abolished all limits between outside and inside-he declares that the two gods are living together in him. Let us distance ourselves from all questions of pathology, and retain this declaration as a valid judgment of his own apprehension of existence. The substitution of the divine names for that of "Nietzsche" immediately touches upon the problem of the identity of the person in relation to a single God, who is the truth, and to the existence of many gods, insofar as they are the explication of being, on the one hand, and an expression of the plurality within a single individual, within each and every individual, on the other.

Thus Nietzsche maintains within himself the image of Christ, or rather, as he says, of the Crucified, a supreme symbol that remains in him as the indispensable opposite of Dionysus. Through their very antagonism, the two names "Christ" and "Dionysus" constitute an equilibrium.

It is clear that this brings us back to the problem of the authentic incommunicable. It is in this context that Karl Löwith, in his important book on the eternal return, poses the following question of credibility to Nietzsche's doctrine: If he is not Dionysus, does not the whole edifice fall into ruin? ${ }^{27}$ But I am claiming that this question does not see in what sense the simulacrum can or cannot give an account of the authentic.

When Nietzsche announces that God is dead, this amounts to saying that Nietzsche must necessarily lose his own identity. What is presented here as an ontological catastrophe corresponds exactly to the re-absorption of both the true world and apparent world into the fable. Within the fable, there is a plurality of norms; or rather, there is no norm at all properly speaking, because the very principle of a responsible identity is unknown in the fable, insofar as existence is neither clarified nor revealed in the physiognomy of a unique God who, as the judge of a responsible self, would 
extract the individual from a potential plurality.

God is dead does not mean that the divinity ceases to act as a clarification of existence, but rather that the absolute guarantee of the identity of the responsible self vanishes from the horizon of Nietzsche's consciousness, which in turn merges with this disappearance.

If the concept of identity vanishes, at first sight all that remains is the fortuitousness that befalls consciousness. Up until then, consciousness recognized the fortuitous by virtue of its apparently necessary identity, which judges that all things around it are either necessary or fortuitous.

But, as soon as the fortuitous is revealed to consciousness as the necessary effect of a universal law, as the wheel of fortune, it can consider itself to be fortuitous. All that remains for consciousness is to declare that its own identity is a fortuitous case arbitrarily maintained as necessary, even if this means understanding itself through this universal wheel of fortune, and even if this means embracing (if possible) the totality of cases-fortuitousness itself in its necessary totality.

What subsists then is being, and the verb "to be" is never applicable to being itself, but to the fortuitous. In Nietzsche's declaration, "I am Chambige, I am Badinguet, I am Prado... At bottom I am every name in bistory," 28 we can see his consciousness enumerating, like so many drawings in a lottery, the different possibilities of being that, taken together, would be being itself. These different possibilities make use of the momentary success that is named Nietzsche, but who, as a success, winds up abdicating himself for a more generous demonstration of being. "In the end I would much rather be a Basel professor than God; but I have not dared push my personal egoism so far as to desist for its sake from the creation of the world... One must make sacrifices however and wherever one lives." 29

Existence as the eternal return of all things is produced in the physiognomies of as many multiple gods as it has possible manifestations in the souls of men. If the will adheres to this perpetual movement of the universe, what it 
contemplates is first the wheel of the gods, as it is said in Zaratbustra: The universe is only "many gods eternally fleeing and reseeking one another, many gods blissfully self-contradicting, communing again and belonging again to one another." 30

No doubt, the Nietzschean version of polytheism is necessarily as distant from the devotion of antiquity as his concept of a divine instinct generating many gods is necessarily distant from the Christian notion of divinity. But what this "version" shows is the refusal to settle into an atheistic morality that, for Nietzsche, was no less suffocating than the monotheistic morality. He could not help but see in atheistic and humanistic morality merely the continuation of what he felt was the tyranny of a unique truth, whatever its name might be-whether it appeared in the form of a categorical imperative or as the physiognomy of an exclusive and personal God. Thus, the disbelief in a unique and normative God, in a God who is the Truth, is nonetheless affirmed as an impiety that is divinely inspired, which forbids any re-folding of reason back into strictly human limits. Nietzschean impiety not only discredits rational man, but remains complicit with all the phantasms that are reflections in the soul of everything that man has had to expel in order to arrive at a rational definition of his nature. This impiety, however, does not aspire to a pure and simple unleashing of blind forces, as some are often led to say with regard to Nietzsche. He has nothing in common with a vitalism that would make a clean slate of all of the elaborated forms of culture. Nietzsche is at the antipodes of any naturalism; and his impiety declares itself to be a tributary of his culture. This is why one finds, in Zarathustra's incantation, something like an appeal to an insurrection of images-those images that the human soul is able to form, in its phantasms, from its own obscure forces. These phantasms testify to the soul's aptitude for an always-inexhaustible metamorphosis, its need for an unappeasable and universal investment, in which various diverse extra-human forms of existence are offered to the soul as so many possibilities of being-stone, plant, animal, star-but precisely insofar as they 
would always be possibilities for the life of the soul itself. This aptitude for metamorphosis (which, under the regime of an exclusive normative principle, is one of the major temptations that man has had to struggle against for millennia in order to conquer and define himself) has not itself contributed to the eliminatory formation that had to lead to man. The proof of this can be found in the delimitation of the divine and the human, and in that admirable compensation by which man-to the extent that he renounces his bestiality, vegetality, and minerality, and hierarchizes his desires and passions according to always-variable criteria-reveals within himself an analogous hierarchy in regions that are supra- or infra-worldly. The universe is populated by many divinities, by various divinities of both sexes, and thus divinities that are capable of pursuing, fleeing from, and uniting with each other. So it was at that moment when the surprising equilibrium of the world blossomed into myth, when-thanks to the simulacra of multiple gods, diverse with regard to their gender and $\operatorname{sex}^{31}$-neither "conscious" nor "unconscious," neither "outside" nor "inside," neither "obscure forces" nor "phantasms" preoccupied the mind, once the entire soul managed to situate these images in space, and to render them indistinguishable from the soul. Out of this relation between the divine and the human, moral monotheism has achieved the conquest of man by himself, and has subjugated nature to man by enabling the anthropological phenomenon of science. Moreover, according to Nietzsche, after two millennia this relation has provoked that profound disequilibrium which has resulted in the disarray of nihilism. Hence the alienation of the universe from man, which Nietzsche discerned in the exploration of the universe by science; and hence the loss of what is expressed by this nostalgia for the soul (as capable of metamorphosis): the fundamental eros that makes man, as Nietzsche says, the animal who reveres. ${ }^{32}$ What becomes apparent, then, is that the event of the "death of God" stirs the eros of the soul at its root; it awakens the instinct of adoration, this instinct that generates gods, which in Nietzsche is both a creative 
will and a will to eternalization. ${ }^{33}$ The "death of God" means that a rupture is introduced into this eros, which is then split into two contrary tendencies: the will to self-creation, which is never without destruction, and the will to adore, which is never willed without willing eternalization. Insofar as the will to power is simply another term for this set of tendencies and constitutes the universal capacity for metamorphosis, it finds something of a compensation, or a kind of healing, in its identification with Dionysus, in the sense that, in Nietzsche, this ancient god of polytheism would express and combine within himself all the dead and resurrected gods.

Zarathustra himself accounts for the dissociation of these two willings (the will to create and the will to adore) when he demands the creation of new values-and thus new truths, which man would not know how to either believe or obey, since they would be marked with the seal of distress and destruction. It would be impossible for the will to create new values to ever appease the need to adore, since this need is implicit in the will to eternalization of oneself. If man is an animal that reveres, he would only know how to revere what comes to him from the necessity of being-by virtue of which he cannot not will to be. For this reason, he would not know how to either obey or believe in the values he deliberately creates, were it not a matter of the very simulacra of his need for eternity. Hence the alternation, in Zarathustra, between the will to create, in the absence of gods, and the contemplation of the dance of the gods, which explains the universe. It is when he announces that all the gods are dead that Zarathustra demands that what must now live is the overman, that is, a humanity that knows how to overcome itself. How is it overcome? By rewilling that everything that already was be reproduced, and to do this as its own activity. This act is defined as the will to create: as Zarathustra declares, "if there were gods, what would there be to create?" 34 But what is it that leads man to create if not the law of the eternal return, to which he decides to adhere? 'To what does he adhere if not a life that he has forgotten, but which the revelation of the eternal return as law incites 
him to re-will? And what does he re-will if not that which he now does not want to will? Is this to say that the absence of gods incites him to create new gods? Or does he want to prevent the return of those ages when he adored the gods? In re-willing the gods, does he make man move to a higher life? But how would this life be a higher life, if it tends toward that which already was? In other words, how could it be a higher life if it tends toward a state where it does not want to create, but would rather adore the gods? Once again, it would thus seem that the doctrine of the eternal return is conceived as a simulacrum of a doctrine, whose parodic character gives an account of bilarity as an attribute of existence--an attribute that becomes sufficient to itself when laughter bursts from the ground [fond] of the whole truth, either because the truth explodes in the laughter of the gods, or because the gods themselves die from a mad laughter.

When a god wanted to be the only God, all the other gods were seized by a mad laughter, to the point where they died laughing. ${ }^{35}$

For what is the divine, if not the fact that there are many gods and not a single God?

Laughter is here like the supreme image, the supreme manifestation of the divine reabsorbing the announced gods, and announcing the gods with a new burst of laughter; for if the gods are dying from this laughter, it is also from this laughter that bursts from the ground of the whole truth that the gods are reborn.

We must follow Zarathustra to the end of his adventure in order to see the refutation of this need to create for and against necessity, which denounces the solidarity between the three forces of eternalization, adoration and creation-the three cardinal virtues in Nietzsche. In this refutation, we can see that the death of God and the distress of the fundamental eros, the distress of the need to revere (a distress that the will to create turns from in derision as its own failure), are identical. For if it is the failure of a single instinct, the derision that compensates for it is nonetheless inscribed in the necessity 


\section{PIERRE KLOSSOWSKI}

of the eternal return. Once he has willed the eternal return of all things, Zarathustra has chosen in advance to see his own doctrine turned from in derision, as if laugbter, that infallible murderer, were both the best inspirer of the doctrine as well as its best denigrator. Thus the eternal return of all things also wills the return of the gods. What other meaning than this can be attributed to the extraordinary parody of the Communion, in which God's murderer is also the person who offers the chalice to the ass: a sacrilegious figure of the Christian God from pagan times, but more specifically a sacred animal in the ancient mysteries, the Golden Ass of the Isiac ${ }^{36}$ initiation, an animal worthy of its tireless "Ia!" 37 - its tireless yes lets all things return-worthy of representing the long suffering of the divine, worthy also of incarnating an ancient divinity, Dionysus, the god of the vine, resurrected in general drunkenness. Thus, finally, as the Wanderer tells Zarathustra: "in the case of gods, death is always a mere prejudice." 38

Translated by Russell Ford

\section{Notes}

All notes are the translator's except where otherwise indicated. The translator gratefully acknowledges the help of the following during the preparation of this translation: Ian James, Bryan Lueck, Holly Moore, Michael Naas and Allan Stoekl. Special thanks go to Dan Smith who graciously read through the entire essay and made a number of excellent corrections and suggestions.

${ }^{1}$ Klossowski is referring to the work of Charles Andler, Nietzsche, sa vie et sa pensée, 3 vols. (Paris: Gallimard, 1958).

2 "Let there be truth and let life perish." Friedrich Nietzsche, Untimely Meditations, trans. R.J. Hollingdale (New York: Cambridge University Press, 1983), §4, 78.

3 "What an artist perishes with me." These are the last words attributed to the Roman emperor Nero. Nietzsche quotes them in The Gay Science, trans. Walter Kaufmann (New York: Vintage, 1974), Book 1, 
$\$ 36,105$.

${ }^{4}$ Friedrich Nietzsche, Ecce Homo, in Basic Writings of Nietzsche, ed. and trans. Walter Kaufmann (New York: Modern Library, 1992), "Thus Spoke Zarathustra: A Book for All and None," \$5, 759.

${ }^{5}$ Friedrich Nietzsche, Twilight of the Idols, trans. Walter Kaufmann, in The Portable Nietasche (New York: Viking Press, 1954), 485486.

${ }^{6}$ A portmanteau word, "sous-vient" is coined by Klossowski from the preposition "sous," meaning "under" or "beneath" (also used as a prefix usually translated as "sub-"), and the third person present, indicative form of "venir," meaning "to come." "Sous-vient" also echoes the word "souvenir," both a noun meaning "memory," and a verb meaning "to remember." Finally, it also echoes, though to a lesser extent, the verb "soutenir," meaning "to bear," or "to sustain." It thus carries a sense of remembrance as something that is "undergone," or that one succumbs to (an inactivity of consciousness preparatory for the coming forth [advient, in the next sentence] of the past).

${ }^{7}$ Friedrich Nietzsche, Thus Spoke Zarathustra, in The Portable Nietzsche (New York: Viking Press, 1954), Second Part, "On Redemption," 253. modified.
${ }^{8}$ Nietzsche, Gay Science, Book 3, $\$ 112,172$.
${ }^{9}$ Nietzsche, Gay Science, Book 3, \$111, 171-172.
${ }^{10}$ Nietzsche, Gay Science, Book 3, \$110, 169-171.
${ }^{11}$ Nietzsche, Gay Science, Book 3, $\$ 110,171$, emphasis added.
${ }^{12}$ Nietzsche, Gay Science, Book 3, \$110, 169-171, translation

${ }^{13}$ Ephesians 5:13.

${ }^{14}$ Ephesians 5:11.

${ }^{15} \mathrm{John} 1: 5$.

${ }^{16}$ Nietzsche, Gay Science, Book 5, §354, 297-300.

${ }^{17}$ Ibid.

18 "Dépense" means, literally, "expenditure," or "waste;" the verb "dépenser" can also mean "to consume." Klossowski uses it to express the non-goal-oriented expenditure of unconscious impulses; incommunicable pathos. The contrast between this exertion and that of thinking can be seen in the components of the word itself: "de," a preposition that can have the sense of negation (as in "démonter," "to dis-mount"), and "pense," the imperative form of the verb "penser," "to think." The word thus also carries a sense of "to un-think."

${ }^{19}$ Friedrich Nietzsche, The Will to Power, ed. Walter Kaufmann, trans. Walter Kaufmann and R. J. Hollingdale (New York: Vintage Books, 1967), Book 3, Section 4, \$493 [1885], 272.

${ }^{20}$ Nietzsche, Gay Science, Preface to the Second Edition, $\$ 1,33$, 


\section{PIERRE KLOSSOWSKI}

translation modified.

${ }^{21}$ Nietzsche, Gay Science, $\$ 1,74-76$.

${ }^{22}$ Ibid.

${ }^{23}$ See Nietzsche, Will to Power, Book 3, Section IV, \$853, “Art in The Birth of Tragedy," 451.

${ }^{24}$ Zarathustra first encounters The Last Pope in Thus Spoke Zaratbustra, Fourth Part, \$6, "Retired," 370-375.

${ }^{25}$ Nietzsche, Gay Science, Book 5, \$361, 316-317.

${ }^{26}$ Nietzsche, Ecce Homo, "Why I Am A Destiny," §9, in Basic Writings of Nietzsche, 791.

${ }^{27}$ Klossowski is referring to Karl Löwith, Nietzsche's Pbilosopby of the Eternal Return of the Same, Trans. J. Harvey Lomax (Berkeley: University of California Press, 1997).

${ }^{28}$ Nietzsche, Letter to Jacob Burckhardt, dated January 6, 1889, in The Portable Nietzsche, 686.

${ }^{29} \mathrm{Ibid}, 685$.

${ }^{30}$ Nietzsche, Thus Spoke Zaratbustra, Third Part, "On Old and New Tablets," $\$ 2,309$, translation modified.

${ }^{31}$ What is glimpsed here is not the return of a demonology (obscure forces as demons) but a theogony (psychic dispositions as divinities; antagonistic and conciliatory dispositions as divinities given to quarreling and coupling). The demonology of Neoplatonic origin was already tending toward a psychology, a kind of figurative psychology. Pantheology, on the other hand, presupposes a notion of space where the inner life of the soul and the life of the cosmos form a single space, in which the event-which, for us, is "psychological"-is situated as a spatial fact. This is why the pan-theology of myth-with its genealogies of divinities, its amorous adventures of gods and goddesses-creates an equilibrium between man and his own forces, for the latter find their physiognomies in the eternal figure of the gods. The practical consequences of such an equilibrium are the exact opposite of those that follow from a purely psychological conception-that is, conscience and the will, and hence the morality of behavior. In a theogony, what reigns is simply an exchange or commerce between the favor and disfavor of being: the physiognomy of some god who attracts or repulses the physiognomy of some goddess, according to the rule of the law of the chase, of erotic attraction. However, this is not what we have been led to call a pure transposition of human experience, but rather a process that belongs to the very manifestations of being: the commerce of the sexes in the form of divinities is simply an explication of being in its modes of appearing and disappearing, whereas in its human form this same exchange is simply the experience of living and dying. What we call theogony is nothing other than a necessary participation in the explications of being in divine 


\section{NIETZSCHE, POLY'THEISM, AND PARODY}

physiognomies. AUTHOR.

${ }^{32}$ Nietzsche, Gay Science, Book 5, $₫ 346,285-287$.

${ }^{33}$ Nietzsche, Gay Science, Book 5, \$370, 327-331.

${ }^{34}$ Nietzsche, Thus Spoke Zarathustra, Second Part, "Upon the Blessed Isles," 199, translation modified.

${ }^{35}$ Nietzsche, Thus Spoke Zaratbustra, Third Part, "On Apostates," $\$ 2,294$.

${ }^{36}$ Of or relating to the pagan Isis cults.

37 "Ita est?"-AUTHOR. "Ita est" is the refrain of the ass during the "Ass Festival" in the Fourth Part of Thus Spoke Zarathustra, 425-436. It is a Latin phrase meaning, literally, "it is indeed." Kaufmann translates it as "Yea-Yuh"; Hollingdale as "Ye-a."

${ }^{38}$ Nietzsche, Thus Spoke Zarathustra, Fourth Part, "The Ass Festival," $\$ 1,426$, translation modified. 